Plas, A.G.M. van der, Onwuteaka-Philipsen, B.D., Vissers, K.C., Deliens, L., Jansen, W.J.J., Francke, A.L. Appraisal of cooperation with a palliative care case manager by general practitioners and community nurses: a cross-sectional questionnaire study. Journal of Advanced Nursing: 2016, 72(1), 147-157

\begin{tabular}{|c|c|}
\hline $\begin{array}{l}\text { Postprint } \\
\text { Version }\end{array}$ & 1.0 \\
\hline Journal website & $\frac{\text { http://onlinelibrary.wiley.com/doi/10.1111/jan.12818/abstract;jsessionid=2F476E2 }}{\text { 8075A7FEFDBAF9C4D8DEA4C78.f03t04 }}$ \\
\hline Pubmed link & http://www.ncbi.nlm.nih.gov/pubmed/26412020 \\
\hline DOI & 10.1111/jan.12818 \\
\hline
\end{tabular}

This is a NIVEL certified Post Print, more info at http://www.nivel.eu

\title{
Appraisal of cooperation with a palliative care case manager by general practitioners and community nurses: a cross-sectional questionnaire study
}

ANNicka G.M. VAn DER Plas, BregJe D. OnwUteaka-Philipsen, Kris C. Vissers, LuC DELIENS, WIM J.J. JANSEN \& ANNEKE L. FRANCKE

\begin{abstract}
Aims

To investigate how general practitioners and community nurses value the support that they receive from a nurse case manager with expertise in palliative care, whether they think the case manager is helpful in realizing appropriate care and what characteristics of the patient and case management are associated with this view.

Background

For sustainable palliative care in an ageing society, basic palliative care is provided by generalists and specialist palliative care is reserved for complex situations. Acceptance of and cooperation with specialist palliative care providers by the general practitioner and community nurse is pivotal.

Design

Cross-sectional questionnaire study.

Methods

Questionnaire data from 168 general practitioners and 125 community nurses were analysed using chi-square tests, univariate and multivariate logistic regression. Data were gathered between March 2011-December 2013.

Results

Of general practitioners, $46 \%$ rated the case manager as helpful in realizing care that is appropriate for the patient; for community nurses this was $49 \%$. The case manager did not hinder the process of care and had added value for patients, according to the general practitioners and community nurses. The tasks of the case manager were associated with whether or not the case manager was helpful in realizing appropriate care, whereas patient characteristics and the number of contacts with the case manager were not.

Conclusion
\end{abstract}


Plas, A.G.M. van der, Onwuteaka-Philipsen, B.D., Vissers, K.C., Deliens, L., Jansen, W.J.J., Francke, A.L. Appraisal of cooperation with a palliative care case manager by general practitioners and community nurses: a cross-sectional questionnaire study. Journal of Advanced Nursing: 2016, 72(1), 147-157

General practitioners and community nurses are moderately positive about the support from the case manager. To improve cooperation further, case managers should invest in contact with general practitioners and community nurses.

\section{INTRODUCTION}

The aim of palliative care is to improve the quality of life of patients and their families when facing the problems associated with life-threatening illness, as stated in the World Health Organization (WHO) definition (Sepulveda et al. 2002). Most people prefer to die at home (Gomes et al. 2013), so the availability of communitybased palliative care is important in enabling patients' palliative care wishes and needs to be met.

In the Netherlands, the general practitioner (GP) and the Registered Nurses working in the community and delivering care to patients at home (hereinafter referred to as 'community nurses') are main care providers for patients with palliative care needs who are living in the community. Patients have a broad range of symptoms and it is hard to keep up to date with the new, advanced and complex treatment options now available in palliative care (Groot et al. 2005, Shipman et al. 2008, Becker et al. 2010). Nurse case managers with specific expertise in palliative care have been introduced to help patients and their informal carers obtain the palliative care that matches their preferences. Primary palliative care in the Netherlands is an example of a model of care where generalist and specialist palliative care providers work together (Quill \& Abernethy 2013).

To ensure continuity of care, a case manager collaborates with the patient, their informal carers and the professionals involved in care for the patient, such as the GP or the medical specialist (Minkman et al. 2009). The case manager provides advice to patients and their informal carers and refers them to other care providers when necessary. Additionally, the case manager may offer advice and information about good palliative care to other healthcare providers involved with the patient, usually the GP and the community nurse. When cancer patients receive additional support from a case manager, the place of death is more likely to be at the home and there are fewer hospitalizations in the last 30 days of life, compared with patients receiving standard GP care (without additional support from a case manager) (van der Plas et al. 2015c).

\section{Background}

It is pivotal that the GP and community nurse should accept and cooperate with the specialized palliative care case manager, as case managers have an advisory role towards patients, informal carers and other healthcare professionals (they do not take over care). However, ambiguity towards such collaboration is difficult to overcome. It is known that the GPs and community nurses have expressed a fear of 'erosion' of their own tasks, a feeling that their own contribution was underrated and a fear of losing control over the patient as a result of involvement of specialized palliative care at home (Seamark et al. 1993, Walshe et al. 2008). Willingness to consult a palliative care specialist depends on previous experiences of collaboration (Walshe et al. 2008, Dahlhaus et al. 2013). A systematic review of how the partnership between generalist and specialist palliative care services works identified five key factors that support partnership: good communication between providers; opportunities for education; clear definition of roles and responsibilities; accessibility of specialist palliative care; 
Plas, A.G.M. van der, Onwuteaka-Philipsen, B.D., Vissers, K.C., Deliens, L., Jansen, W.J.J., Francke, A.L. Appraisal of cooperation with a palliative care case manager by general practitioners and community nurses: a cross-sectional questionnaire study. Journal of Advanced Nursing: 2016, 72(1), 147-157

and coordinated and continuous support (Gardiner et al. 2012). However, that review included a wide range of generalist and specialist care providers (e.g. collaboration between heart failure nurses and MacMillan nurses, hospital staff working together with a specialist palliative care team in a hospital).

For patients with palliative care needs who live in the community, cooperation between the primary care team and specialized palliative care providers is key. There are few studies on cooperation where both Registered Nurses working in primary care and GPs are included but reported on separately. A Danish study (Goldschmidt et al. 2005) investigated the experiences of GPs and district nurses with a palliative home-care team after participation in a home conference. The palliative home-care team consisted of specialized doctors and nurses who visited the patient at home on a regular basis and proposed treatment changes to the GP and district nurse. In that study, GPs and district nurses welcomed the palliative home-care team and most of them experienced benefits to patients. Dissatisfaction was caused mainly by a lack of information from the home-care team to the primary care professionals. This study used open-ended questions and the opinions of the GP and district nurses could not be compared statistically. Furthermore, specialized care was given by a team of doctors and nurses, and GPs and district nurses may have different expectations from a team or expectations may differ from when specialized care is provided by a doctor or a nurse. A study conducted in the UK (Seamark et al. 1993) investigated knowledge and perceptions of a domiciliary hospice service (12 MacMillan nurses, providing 24-hour cover 7 days a week, two social workers and volunteers) by general practitioners and community nurses. The domiciliary hospice service was highly appreciated, although ambiguity towards cooperation was expressed (see above). No statistical comparison was made between the answers from the general practitioners and community nurses. Also, this study involved a service that offered hands-on patient care, which may yield different results. To date there are no studies on cooperation (between palliative care case managers and the primary care team) where both community nurses and GPs are included but reported on separately. Furthermore, studies into specialized care mainly focus on evaluating the content of the support that is provided and do not take patient and contact characteristics into account.

\section{THE STUDY}

\section{Aims}

The aim of this study was to evaluate the experiences of GPs and community nurses with a palliative care case manager, answering the following research questions: How do GPs and community nurses value the involvement of and their cooperation with the case manager?

According to the GP and community nurse, is the case manager helpful in realizing care that is appropriate for the patient and what characteristics of the patient and case management are associated with this view?

\section{Design}

Cross-sectional questionnaire study.

\section{Setting and participants}

In the Netherlands, palliative care is mainly provided by generalist care providers. Almost all Dutch residents are registered with a GP, who functions as a gatekeeper 
Plas, A.G.M. van der, Onwuteaka-Philipsen, B.D., Vissers, K.C., Deliens, L., Jansen, W.J.J., Francke, A.L. Appraisal of cooperation with a palliative care case manager by general practitioners and community nurses: a cross-sectional questionnaire study. Journal of Advanced Nursing: 2016, 72(1), 147-157

for more specialized forms of care. The number of not-unexpected deaths per GP per year is estimated to be 12-13 on average (IKNL 2014). Community nurses and home support workers who are confronted with end-of-life care see an average of 10 palliative care patients a year (Nursing Staff Panel 2012). Palliative care is part of the educational programme for GPs and community nurses and there is also a wide range of short courses available on palliative care. Specialized palliative care knowledge is made available to GPs and community nurses through consultation teams operating all over the Netherlands, mainly offering advice by telephone.

Nurse case managers with specific expertise in palliative care who visit patients at home have been introduced. A nationwide survey was conducted to identify initiatives involving case managers (van der Plas et al. 2013). The term 'initiative' is used to do justice to organizational differences, as not all case managers work in a team of case managers; there was one initiative with a single case manager, for example while another case manager was part of a team where not all members offer case management. Of the 20 initiatives identified in that survey, 13 were studied in this paper. We received questionnaires from the case managers of 721 patients with at least one contact with the case manager. During the study period, 604 patients died. After the patient's death, 173 GPs and 126 community nurses returned a questionnaire. Of the GPs, 168 had filled in the evaluation questions about the case manager. Of the community nurses, 125 had filled in the evaluation questions about the case manager. Community nurses may not have been involved in care for all patients.

\section{Data collection}

Data were gathered from March 2011 until the end of 2013. The case managers completed a questionnaire after a patient was referred to them. After the patient's death, the case manager sent questionnaires to the GP and community nurse (if involved). After it was filled in, it could be sent directly to the researcher so the case manager did not see the answers. All three questionnaires used the same unique patient identification number. If no questionnaire was received from the GP or community nurse, the researcher asked the case manager to send a reminder. Case managers who support many patients had the option of including every second patient in the study rather than every patient.

Three questionnaires were used: one for the case manager, one for the GP and one for the community nurse. The questionnaire for the case manager contained structured questions about characteristics of the patient, such as demographic data and the diagnosis. The questionnaires for the GP and the community nurse contained structured questions about the care they provided for the patient and on their cooperation with other professionals. Their cooperation with the case manager was rated in 14 questions (see Table 2 and Figure 1 for the content of those questions). Twelve questions used a 5-point Likert scale with the following options: $1=$ totally disagree; 2 = disagree; $3=$ neutral; $4=$ agree; $5=$ totally agree. The question about earlier experience with a case manager had three response options (yes, I've heard of them; yes, I've worked with one before; no). The question about future referral to a case manager used four response options (never; in some cases; in most cases; always). Information about contacts between the case manager and the $\mathrm{GP} /$ community nurse was asked as follows: 'How often did you have contact with the case manager in the scope of care for this patient? You can give an estimate.' This was asked for the following time frames: in the last week of the patient's life, in 
Plas, A.G.M. van der, Onwuteaka-Philipsen, B.D., Vissers, K.C., Deliens, L., Jansen, W.J.J., Francke, A.L. Appraisal of cooperation with a palliative care case manager by general practitioners and community nurses: a cross-sectional questionnaire study. Journal of Advanced Nursing: 2016, 72(1), 147-157

weeks 2-4, in months 2-3, and in months 4-12 before death. Information about contacts between the case manager and patients came from a registration form described elsewhere (van der Plas et al. 2015b).

\section{[FIGURE 1]}

\section{Ethical considerations}

Under Dutch law, ethics approval was not required as the study did not involve imposing any interventions or actions (Centrale Commissie Mensgebonden Onderzoek 2014).

\section{Data analysis}

For the 5-point Likert scale questions that the GP and community nurse answered, scores were recoded into two categories: 'agree' and 'totally agree' were grouped together and the scores for 'neutral', 'disagree', 'totally disagree' and 'don't know' were also grouped together. When a single item was left unanswered by the GP or community nurse, this was interpreted as 'don't know'.

Chi-square values were calculated for the evaluation by the GP and community nurse of the care by the case manager. Univariate and multivariate logistic regression was used to investigate factors associated with whether the GP and community nurse perceived the case manager as helpful in realizing appropriate care for the patient. Separate models were made for the GPs and community nurses. The age of the patient was entered as a continuous variable and the first contact between the case manager and community nurse and GP was recoded into a categorical variable containing three categories (no contact; first contact in the last month before the patient's death; first contact more than one month before the patient's death). All other variables were dichotomized. Patient characteristics, items about the contact between the case manager and patients and the GP and community nurse and evaluation of tasks of the case manager by the GP and community nurse were first entered as univariate. If an item was significantly related to the evaluation question, it was then entered in a backwards logistic regression procedure (removal at $\mathrm{P}>0 \cdot 10)$. First, a regression model was fitted containing the items about contact of the case manager with patients and the GP and community nurse. Another regression model was fitted containing the evaluation of tasks of the case manager by the GP and community nurse. This was done so that contacts and tasks could be investigated independently of each other. The items that were significant in the two separate models were then entered in a backward logistic regression procedure to investigate which items would remain significant (whether items about contacts would remain significant when the tasks of the case manager were taken into account and vice versa). Data were analysed using SPSS, IBM Statistics for Windows version 20.0 (IBM 2011).

\section{Rigour}

The study was set up to investigate the implementation and outcomes of the support provided by case managers in primary palliative care. The questionnaires were piloted on a small sample of respondents to ascertain that questions were clearly formulated and relevant. This led to some minor changes in the wording of the questions. The case managers received verbal and written instructions on data collection at the start of the study and the researchers were available during the study period to answer questions by telephone or e-mail as needed. Only variables that 
Plas, A.G.M. van der, Onwuteaka-Philipsen, B.D., Vissers, K.C., Deliens, L., Jansen, W.J.J., Francke, A.L. Appraisal of cooperation with a palliative care case manager by general practitioners and community nurses: a cross-sectional questionnaire study. Journal of Advanced Nursing: 2016, 72(1), 147-157

were significantly related to the evaluation question in univariate analyses were entered in the multivariate logistic regression procedure. External validity is enhanced because this paper is based on findings from 13 of the 20 initiatives for case managers in the Netherlands.

\section{RESULTS}

\section{Response: characteristics of patients and of care provision}

After the patient's death $(\mathrm{n}=604$ patients), $168(28 \%)$ GPs and $125(21 \%)$ community nurses completed the evaluation questions about the case manager. Community nurses may not have been involved in care for all patients. For the questionnaires sent back by the GPs, patients had a mean age of $66 \cdot 4$ years (SD 12.3; range 31-92) and half the patients were male (50.6\%). For the questionnaires sent back by the community nurses, patients had a mean age of 68.5 years (SD 11.6; range $37-92)$ and half the patients were male (50.4\%). Most patients had a diagnosis of cancer and less than half had one or more additional diagnoses (see Table 1). More than half of the patients had no limitations in their functional status, or were limited to light activities or bedridden for only part of the day. The informal carers most often involved were the partner and children of the patient. Less than half of patients and/or informal carers had six or more contacts with the case manager. In $42.3 \%$ and $34.4 \%$ of patients respectively, there was no contact between the case manager and the GP and community nurse.

\section{[TABLE 1]}

Evaluation of support from the case manager by the GPs and community nurses In general, Table 2 shows that community nurses were positive more often about the support provided by the case manager than the GPs were. On 7 of 12 items (excluding the item about earlier experiences), the community nurses gave a higher score for support from the case manager than GPs did.

\section{[TABLE 2]}

\section{Is the case manager helpful in realizing appropriate care for the patient and what characteristics of patients and case management are associated with this view?}

Figure 1 shows percentages of GPs and community nurses who said that the case manager helped to realize care that was appropriate for the patient. The GP was more likely to consider the case manager was helpful in realizing appropriate care (Table 3) when the case manager helped with referral to other care providers $(\mathrm{OR}=6 \cdot 33$; CI $2 \cdot 50-16 \cdot 01)$, when the case manager took care of things they themselves did not have time for $(\mathrm{OR}=5 \cdot 44$; CI $2 \cdot 03-14 \cdot 58)$ and when it was clear what kind of support the GP could expect from the case manager $(\mathrm{OR}=3 \cdot 18$; CI $1 \cdot 32-7 \cdot 65)$.

\section{[TABLE 3]}

The community nurse was more likely to consider the case manager was helpful in realizing appropriate care (see Table 4 ) when the case manager helped with referral to other specialized palliative care $(\mathrm{OR}=6 \cdot 63$; CI $2 \cdot 30-19 \cdot 10)$, when the community 
Plas, A.G.M. van der, Onwuteaka-Philipsen, B.D., Vissers, K.C., Deliens, L., Jansen, W.J.J., Francke, A.L. Appraisal of cooperation with a palliative care case manager by general practitioners and community nurses: a cross-sectional questionnaire study. Journal of Advanced Nursing: 2016, 72(1), 147-157

nurse knew when the case manager could be contacted $(\mathrm{OR}=3 \cdot 65$; CI $1 \cdot 23-10 \cdot 81)$ and when the case manager helped with referral to other care providers $(\mathrm{OR}=3 \cdot 21$; CI 1·30-7·93).

\section{[TABLE 4]}

\section{DISCUSSION}

The large majority of GPs and community nurses indicated that the case manager did not hinder the care process and had added value for patients. Community nurses were positive more often about the support provided by the case manager than the GPs were. About half of GPs and community nurses said that the case manager helped to realize care that was appropriate for the patient. The tasks of the case manager, rather than characteristics of patients and contacts, determined whether GPs and community nurses experienced the support by the case manager as being helpful in realizing care that was appropriate for the patient.

\section{Coordinated and continuous support and a clear definition of roles and responsibilities}

Looking at the tasks of the case managers that were perceived as helpful in realizing care that was appropriate for the patient, two tasks are linked with continuity of care and the three other tasks are linked to accessibility and a clear definition of roles and responsibilities. This is consistent with findings from the systematic review on how partnerships function between generalist and specialist palliative care services mentioned earlier (Gardiner et al. 2012).

\section{Community nurses were positive more often than the GPs about the support provided by the case manager}

This is the first study to compare the opinions of GPs and community nurses; the studies mentioned earlier (Seamark et al. 1993, Goldschmidt et al. 2005) were not able to make a statistical comparison. The reason why the community nurses were positive more often than the GPs may be that the community nurses have a better understanding of the demarcation of tasks, as both the community nurse and case manager have nursing backgrounds. The growth of home-care organizations and financial constraints hampered collaboration between GPs and community nurses (de Putter et al. 2014) and GPs' understanding of the work of community nurses has diminished (Burt et al. 2005). It may therefore also be more difficult for GPs to grasp the role of the case manager in relation to their own work and that of the community nurse. Seen in this light, it is interesting that the GPs thought the case manager helped to realize appropriate care for the patient when the case manager took care of things that the GP did not have time for. This was also an observed benefit in a study on collaboration in care for the elders (De Stampa et al. 2013); the case manager contacted nurses and family members and guided follow-up activities and the GP had more time to focus on medical care. Clarity about roles and responsibilities follows from this kind of task division.

Referral practice may also account for some of the differences between GPs and community nurses with regard to their opinions of the case manager. It is known from our previous analyses that patients are mainly (62\%) referred to a case manager by a professional from a hospital (van der Plas et al. 2015a). The fact that the case manager is called in by someone else could be a barrier to cooperation with the GP 
Plas, A.G.M. van der, Onwuteaka-Philipsen, B.D., Vissers, K.C., Deliens, L., Jansen, W.J.J., Francke, A.L. Appraisal of cooperation with a palliative care case manager by general practitioners and community nurses: a cross-sectional questionnaire study. Journal of Advanced Nursing: 2016, 72(1), 147-157

or community nurse. This would be more so for cooperation with the GP than for the community nurse, as the community nurse was not yet involved in the care in $80 \%$ of patients at the moment of referral to a case manager (van der Plas et al. 2015a). It may be that referral practice will gradually change, as this study showed that $64 \%$ of community nurses and $42 \%$ of GPs would refer future patients.

\section{Importance of contact between the case manager, GP and community nurse}

GPs in this study reported that there was no contact between the GP and case manager for $42 \%$ of patients and community nurses had no contact with the case manager for $34 \%$ of patients. Tension between the time spent on direct contact with patients and consultation with other professionals has been noted (Seymour et al. 2002, Pype et al. 2014). However, the case managers should not only collaborate with the patients and their informal carers but also with the professionals involved in care for the patient, such as the GP or the medical specialist, to provide continuity of care for patients (Minkman et al. 2009). Also, task delineation and division will follow from contact. Its importance should therefore not be underestimated, especially as case managers are relatively new in palliative care in the Netherlands (van der Plas et al. 2013). In a study of generalist and specialist palliative care in the United Kingdom (UK) and New Zealand, it was noted that tension between generalist and specialist care providers was less marked in the UK because trust had developed over time, with the UK having a longer history of cooperation between the generalists and specialists (Gott et al. 2012).

\section{Limitations of the study}

Our study was limited to the experiences of GPs and community nurses; the opinions of the bereaved carers will be reported in a separate publication. The response rate is low and response is likely to be skewed towards GPs and community nurses who had sufficient contact with the case manager that they felt able to answer the questions. In some cases where there was little contact, GPs and community nurses were not sent a questionnaire because the case manager believed it might harm future collaboration. Furthermore, the results may only be representative for mixed public-private healthcare systems with a strong primary care gatekeeper, which is the situation in the Netherlands. The case managers had an advisory role with respect to patients and other healthcare professionals. In other healthcare systems, collaboration and interdependencies between generalist and specialist palliative care providers may be different, for instance because there are 'hospice-at-home' teams providing more comprehensive care that extends to prescribing medication and providing hand-on care. Detailed information on the content of the support provided by case managers can be found elsewhere (van der Plas et al. 2015b).

\section{CONCLUSION}

This study provides valuable information on how GPs and community nurses perceive the involvement of a case manager. Differences in evaluation by GPs and community nurses highlight the need for future studies on inter-profession cooperation to include both as separate members of the primary care team. The large majority of GPs and community nurses stated that the case manager did not hinder the care process and did have added value for patients; they are moderately positive about the support they themselves receive from the case manager. As case managers are a relatively new addition to primary palliative care, the working relationship may 
Plas, A.G.M. van der, Onwuteaka-Philipsen, B.D., Vissers, K.C., Deliens, L., Jansen, W.J.J., Francke, A.L. Appraisal of cooperation with a palliative care case manager by general practitioners and community nurses: a cross-sectional questionnaire study. Journal of Advanced Nursing: 2016, 72(1), 147-157

yet improve. To improve cooperation further, case managers should invest in contact with GPs and community nurses. A clear definition of the roles and responsibilities will then follow and trust will develop from there.

\section{Acknowledgements}

We thank Marlies van de Watering for participation and advice in the design and preparation of this study. We thank Anke de Veer and Gwenda Albers for extracting data on palliative care by community nurses and home support workers from the Nursing Staff Panel.

\section{Funding}

The authors thank ZonMw [grant number 80-82100-98-066] for their financial support. The funders had no role in data collection and analysis, selection of respondents, decision to publish or preparation of the manuscript.

\section{Conflict of interest}

The authors declare that they have no conflicts of interest.

\section{REFERENCES}

Becker G., Momm F., Deibert P., Xander C., Gigl A., Wagner B.

\& Baumgartner J. (2010) Planning training seminars in palliative care: a cross-sectional survey on the preferences of general practitioners and nurses in Austria. BMC Medical Education 10, 43.

Burt J., Shipman C., Addington-Hall J. \& White P. (2005) Palliative Care: Perspectives on Caring for Dying People in London. King's Fund Publications, London.

Centrale Commissie Mensgebonden Onderzoek (2014) [Central Committee on Research Involving Human Subjects]. Retrieved from www.ccmo.nl/en on 15 February 2014.

Dahlhaus A., Vanneman N., Siebenhofer A., Brosche M. \& Guethlin C. (2013) Involvement of general practitioners in palliative cancer care: a qualitative study. Supportive Care in Cancer 21(12), 3293-3300.

De Stampa M., Vedel I., Bergman H., Novella J.L., Lechowski L., Ankri J. \& Lapointe L. (2013) Opening the black box of clinical collaboration in integrated care models for frail, elderly patients.

Gerontologist 53(2), 313-325.

Gardiner C., Gott M. \& Ingleton C. (2012) Factors supporting good partnership working between generalist and specialist palliative care services: a systematic review. British Journal of General Practice 62(598), e353-e362.

Goldschmidt D., Groenvold M., Johnsen A.T., Str€omgren A.S., Krasnik A. \& Schmidt L. (2005) Cooperating with a palliative home-care team: expectations and evaluations of GPs and district nurses. Palliative Medicine 19(3), 241-250.

Gomes B., Calanzani N., Gysels M., Hall S. \& Higginson I.J.

(2013) Heterogeneity and changes in preferences for dying at home: a systematic review. BMC Palliative Care 12, 7.

Gott M., Seymour J., Ingleton C., Gardiner C. \& Bellamy G.

(2012) 'That's part of everybody's job': the perspectives of health care staff in England and New Zealand on the meaning and remit of palliative care. Palliative Medicine 26(3), 232241.

Groot M.M., Vernooij-Dassen M.J., Crul B.J. \& Grol R.P. (2005) General practitioners (GPs) and palliative care: perceived tasks and barriers in daily practice. Palliative Medicine 19(2), $111-118$.

IBM (2011) IBM SPSS Statistics for Windows version 20.0. IBM Corp, Armonk, NY.

IKNL (2014) Palliatieve zorg in beeld [An Overview of Palliative Care]. IKNL, Utrecht.

Minkman M.M.N., Ligthart S.A. \& Huijsman R. (2009) Integrated dementia care in The Netherlands: a multiple case study of case management programmes. Health \& Social Care in the Community 17(5), 485-494. 
Plas, A.G.M. van der, Onwuteaka-Philipsen, B.D., Vissers, K.C., Deliens, L., Jansen, W.J.J., Francke, A.L. Appraisal of cooperation with a palliative care case manager by general practitioners and community nurses: a cross-sectional questionnaire study. Journal of Advanced Nursing: 2016, 72(1), 147-157

Nursing Staff Panel (2012) Survey End of Life Care. (Data file; accessed February 2012). NIVEL/VUmc, Utrecht/Amsterdam.

van der Plas A.G.M., Deliens L., van de Watering M., Jansen W.J.J., Vissers K.C. \& Onwuteaka-Philipsen B.D. (2013) Palliative care case management in primary care settings: a nationwide survey. International Journal of Nursing Studies 50 (11), 1504-1512. van der Plas A.G.M., Onwuteaka-Philipsen B.D., Francke A.L., Jansen W.J.J., Vissers K.C. \& Deliens L. (2015a) Palliative care case managers in primary care: a descriptive study on referrals in relation to treatment aims. Journal of Palliative Medicine 18(4), 324-331.

van der Plas A.G.M., Francke A.L., Vissers K.C., Jansen W.J.J., Deliens L. \& OnwuteakaPhilipsen B.D. (2015b) Case management in primary palliative care is associated more strongly with organisational than with patient characteristics: results from a cross-sectional prospective study. BMC Palliative Care 13, 31.

van der Plas A.G.M., Vissers K.C., Francke A.L., Donker G.A., Jansen W.J.J., Deliens L. \& Onwuteaka-Philipsen B.D. (2015c) Involvement of a case manager in palliative care reduces hospitalisations at the end of life in cancer patients; a mortality follow-back study in primary care. PLoS ONE 10(7), e0133197.

de Putter I.D., Francke A.L., deVeer A.J.E. \& Rademakers J.J.D.J.M. (2014) Kennissynthese. De wijkverpleegkundige van vandaag en morgen. Rollen, samenwerking en deskundigheid van wijkverpleegkundigen [Synthesis of Knowledge. The Community Nurse of Today and Tomorrow. Roles, Cooperation and Competencies of Community Nurses]. Nivel, Utrecht.

Pype P., Mertens F., Wens J., Stes A., Van den E.B. \& Deveugele M. (2014) Preparing palliative home care nurses to act as facilitators for physicians' learning: evaluation of a training programme. Palliative Medicine 29(5), 12/2014. doi: $10.1177 / 0269216314560391$.

Quill T.E. \& Abernethy A.P. (2013) Generalist plus specialist palliative care - creating a more sustainable model. New England Journal of Medicine 368(13), 1173-1175.

Seamark D.A., Thorne C.P., Jones R.V., Gray D.J. \& Searle J.F.

(1993) Knowledge and perceptions of a domiciliary hospice service among general practitioners and community nurses.

British Journal of General Practice 43(367), 57-59.

Sepulveda C., Marlin A., Yoshida T. \& Ullrich A. (2002) Palliative care: the World Health Organization's global perspective.

Journal of Pain and Symptom Management 24(2), 91-96.

Seymour J., Clark D., Hughes P., Bath P., Beech N., Corner J., Douglas H.R., Halliday D., Haviland J., Marples R., Normand C., Skilbeck J. \& Webb T. (2002) Clinical nurse specialists in palliative care. Part 3. Issues for the Macmillan Nurse role.

Palliative Medicine 16(5), 386-394.

Shipman C., Gysels M., White P., Worth A., Murray S.A., Barclay S., Forrest S., Shepherd J., Dale J., Dewar S., Peters M., White S., Richardson A., Lorenz K., Koffman J. \& Higginson I.J.

(2008) Improving generalist end of life care: national consultation with practitioners, commissioners, academics and service user groups. British Medical Journal 337, a1720.

Walshe C., Told C., Cares A.L. \& Chew-Graham C. (2008) Judgements about fellow professionals and the management of patients receiving palliative care in primary care: a qualitative study. British Journal of General Practice 58(549), 264-272. 
Plas, A.G.M. van der, Onwuteaka-Philipsen, B.D., Vissers, K.C., Deliens, L., Jansen, W.J.J., Francke, A.L. Appraisal of cooperation with a palliative care case manager by general practitioners and community nurses: a cross-sectional questionnaire study. Journal of Advanced Nursing: 2016, 72(1), 147-157

\section{TABLES AND FIGURES}

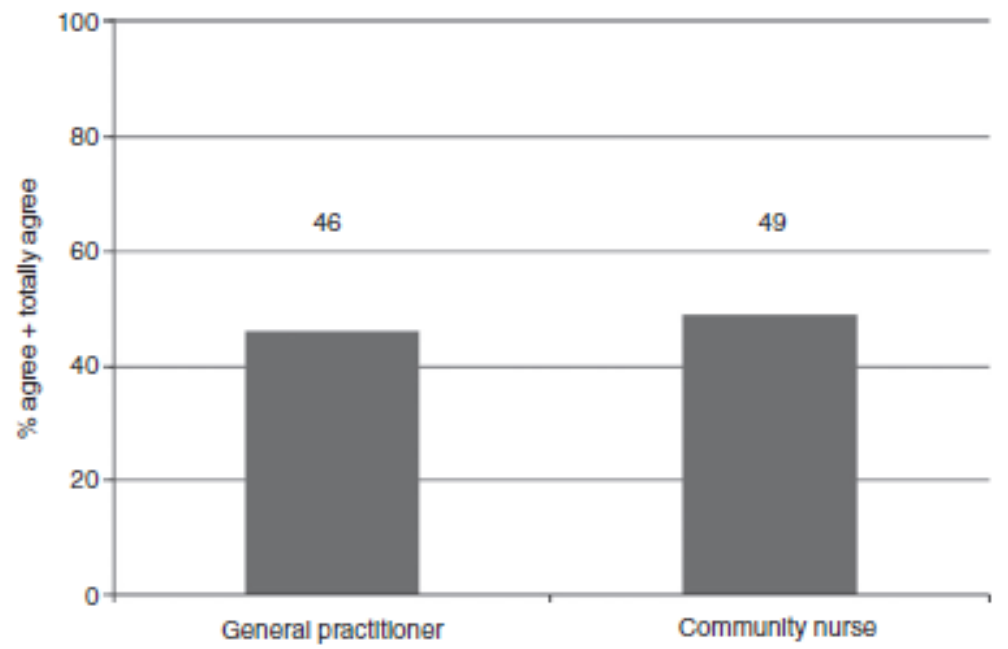

Figure 1 Did the case manager help to realize appropriate care for this patient according to the GP and community nurse? 
Plas, A.G.M. van der, Onwuteaka-Philipsen, B.D., Vissers, K.C., Deliens, L., Jansen, W.J.J., Francke, A.L. Appraisal of cooperation with a palliative care case manager by general practitioners and community nurses: a cross-sectional questionnaire study. Journal of Advanced Nursing: 2016, 72(1), 147-157

Table 1 Characteristics of patients receiving support from a case manager and characteristics of care provision during case management, broken down by questionnaire.

\begin{tabular}{|c|c|c|}
\hline & $\begin{array}{l}\text { GP } \\
\text { questionnaire } \\
(n=168) \\
n(\%)\end{array}$ & $\begin{array}{l}\text { Community } \\
\text { nurse } \\
\text { questionnaire } \\
(n=125) \\
n(\%)\end{array}$ \\
\hline Main diagnosis of cancer & $166(98 \cdot 8)$ & $121(96 \cdot 8)$ \\
\hline At least one other diagnosis & $70(43 \cdot 8)$ & $53(44 \cdot 2)$ \\
\hline \multicolumn{3}{|c|}{ Importance of treatment aims at the start of case management } \\
\hline Mainly palliative treatment aims & $60(37 \cdot 3)$ & $52(44.4)$ \\
\hline $\begin{array}{l}\text { Mainly curative or } \\
\text { life-prolonging treatment aims }\end{array}$ & $5(3 \cdot 1)$ & $1(0 \cdot 9)$ \\
\hline Combined treatment aims & $96(59.6)$ & $64(54 \cdot 7)$ \\
\hline \multicolumn{3}{|l|}{$\begin{array}{l}\text { Functional status at the start } \\
\text { of case management }\end{array}$} \\
\hline Fully functional & $6(3 \cdot 6)$ & $6(4 \cdot 9)$ \\
\hline Limited to light activities & $50(30 \cdot 3)$ & $31(25 \cdot 4)$ \\
\hline Bedridden less than $50 \%$ & $37(22 \cdot 4)$ & $25(20 \cdot 5)$ \\
\hline Bedridden more than $50 \%$ & $41(24 \cdot 8)$ & $35(28 \cdot 7)$ \\
\hline Fully in need of support & $31(18.8)$ & $25(20 \cdot 5)$ \\
\hline \multicolumn{3}{|c|}{ Informal carers (more than one answer possible) } \\
\hline None & $2(1.2)$ & $1(0 \cdot 8)$ \\
\hline Partner & $120(71.9)$ & $76(61 \cdot 3)$ \\
\hline Children & $115(68.9)$ & $82(66 \cdot 1)$ \\
\hline Other family & $45(26.9)$ & $25(20 \cdot 2)$ \\
\hline Other (e.g. friends, neighbours) & $53(31.7)$ & $40(32 \cdot 3)$ \\
\hline $\begin{array}{l}\text { The case manager had six or } \\
\text { more contacts with the patient } \\
\text { and/or informal carer }\end{array}$ & $79(47 \cdot 0)$ & $55(44 \cdot 0)$ \\
\hline \multicolumn{3}{|c|}{$\begin{array}{l}\text { First contact between the case manager and the GP/community } \\
\text { nurse was: }\end{array}$} \\
\hline $\begin{array}{l}\text { In the last week of the } \\
\text { patient's life }\end{array}$ & $25(14.9)$ & $23(18 \cdot 4)$ \\
\hline In weeks $2-4$ before death & $42(25 \cdot 0)$ & $29(23 \cdot 2)$ \\
\hline In months $2-3$ before death & $17(10 \cdot 1)$ & $23(18 \cdot 4)$ \\
\hline In months $4-12$ before death & $13(7 \cdot 7)$ & $7(5 \cdot 6)$ \\
\hline No contact & $71(42 \cdot 3)$ & $43(34.4)$ \\
\hline
\end{tabular}

"In the column for the GP questionnaire, the moment of first contact with the GP and case manager was reported; in the column for the community nurse questionnaire, the moment of first contact with the community nurse and case manager was reported. 
Plas, A.G.M. van der, Onwuteaka-Philipsen, B.D., Vissers, K.C., Deliens, L., Jansen, W.J.J., Francke, A.L. Appraisal of cooperation with a palliative care case manager by general practitioners and community nurses: a cross-sectional questionnaire study. Journal of Advanced Nursing: 2016, 72(1), 147-157

Table 2 Evaluation of support from the case manager by the GP and the community nurse.

\begin{tabular}{|c|c|c|c|}
\hline & $\begin{array}{l}\text { GP } \\
(n=168) \\
n(\%)\end{array}$ & $\begin{array}{l}\text { community } \\
\text { nurse } \\
(n=125) \\
n(\%)\end{array}$ & $P^{*}$ \\
\hline \multicolumn{4}{|c|}{ Task fulfilment of case manager (agree + totally agree) } \\
\hline $\begin{array}{l}\text { Involvement of the case } \\
\text { manager had undesirable } \\
\text { consequences for the care } \\
\text { process }\end{array}$ & $18(10 \cdot 7)$ & $5(4 \cdot 0)$ & 0.035 \\
\hline $\begin{array}{l}\text { Involvement of the case } \\
\text { manager had little added } \\
\text { value for this patient }\end{array}$ & $31(18 \cdot 5)$ & $17(13 \cdot 6)$ & $0 \cdot 267$ \\
\hline $\begin{array}{l}\text { The case manager supported } \\
\text { me or my team }\end{array}$ & $65(38 \cdot 7)$ & $80(64.0)$ & $<0.001$ \\
\hline $\begin{array}{l}\text { Involvement of the case } \\
\text { manager has improved } \\
\text { continuity of care }\end{array}$ & $54(32 \cdot 1)$ & $48(38.4)$ & $0 \cdot 266$ \\
\hline $\begin{array}{l}\text { The case manager helped } \\
\text { to clarify the needs } \\
\text { of the patient }\end{array}$ & $50(29 \cdot 8)$ & $69(55 \cdot 2)$ & $<0.001$ \\
\hline \multicolumn{4}{|c|}{ Tasks of case manager (agree + totally agree) } \\
\hline $\begin{array}{l}\text { I knew when the case } \\
\text { manager could be contacted }\end{array}$ & $69(41 \cdot 1)$ & $90(72 \cdot 0)$ & $<0.001$ \\
\hline $\begin{array}{l}\text { It was clear what kind } \\
\text { of support I could expect } \\
\text { from the case manager }\end{array}$ & $60(35 \cdot 7)$ & $88(70 \cdot 4)$ & $<0.001$ \\
\hline $\begin{array}{l}\text { The case manager helped } \\
\text { with referral to or } \\
\text { involvement of other } \\
\text { care providers }\end{array}$ & $52(31 \cdot 0)$ & $65(52 \cdot 0)$ & $<0.001$ \\
\hline $\begin{array}{l}\text { The case manager helped } \\
\text { with referral to or } \\
\text { involvement of specialized } \\
\text { palliative care }\end{array}$ & $45(26 \cdot 8)$ & $39(31 \cdot 2)$ & 0.409 \\
\hline $\begin{array}{l}\text { The case manager took care } \\
\text { of things I did not have } \\
\text { time for }\end{array}$ & $54(32 \cdot 1)$ & $29(23.2)$ & 0.093 \\
\hline $\begin{array}{l}\text { The case manager helped } \\
\text { coordinate the care by the } \\
\text { care providers involved }\end{array}$ & $33(19 \cdot 6)$ & $34(27 \cdot 2)$ & $0 \cdot 128$ \\
\hline \multicolumn{4}{|c|}{ Earlier experience with case managers } \\
\hline $\begin{array}{l}\text { Were you aware that there } \\
\text { are palliative care case } \\
\text { managers in your region? }\end{array}$ & & & $<0.001$ \\
\hline Yes, I've heard of them & $45(26 \cdot 8)$ & $46(36 \cdot 8)$ & \\
\hline $\begin{array}{l}\text { Yes, I've worked with } \\
\text { one before }\end{array}$ & $68(40 \cdot 5)$ & $66(52 \cdot 8)$ & \\
\hline No & $55(32 \cdot 7)$ & $13(10 \cdot 4)$ & \\
\hline \multicolumn{4}{|c|}{ Future referral to case manager (In most cases + always) } \\
\hline $\begin{array}{l}\text { Would you refer your } \\
\text { patients to a case manager? }\end{array}$ & $71(42 \cdot 3)$ & $80(64.0)$ & $<0.001$ \\
\hline
\end{tabular}

*Chi-square test.

$P$-values below 0.05 are considered statistically significant and are boldfaced. 
Plas, A.G.M. van der, Onwuteaka-Philipsen, B.D., Vissers, K.C., Deliens, L., Jansen, W.J.J., Francke, A.L. Appraisal of cooperation with a palliative care case manager by general practitioners and community nurses: a cross-sectional questionnaire study. Journal of Advanced Nursing: 2016, 72(1), 147-157

Table 3 Logistic regression analyses on characteristics associated with GPs' ratings of whether the case manager helped to realize care that is appropriate for the patient.

\begin{tabular}{|c|c|c|}
\hline & \multicolumn{2}{|c|}{$\begin{array}{l}\mathrm{GP}(n=168)^{*} \\
\text { The case manager helped to } \\
\text { realize/accomplish appropriate } \\
\text { care for this patient } \\
\text { (reference = do not agree, } \\
\text { totally disagree, don't know) }\end{array}$} \\
\hline & $\begin{array}{l}\text { Univariate } \\
\text { OR }(\mathrm{CI})\end{array}$ & $\begin{array}{l}\text { Multivariate }^{\dagger} \\
\text { OR (CI) }\end{array}$ \\
\hline \multicolumn{3}{|l|}{ Patient characteristics } \\
\hline Age of patient & $1.01(0.98-1.03)$ & \\
\hline $\begin{array}{l}\text { Sex of patient } \\
\text { (reference }=\text { male) }\end{array}$ & $0.91(0.49-1.66)$ & \\
\hline $\begin{array}{l}\text { Patient lives alone } \\
\text { (reference }=\text { no) }\end{array}$ & $0.58(0.26-1.31)$ & \\
\hline $\begin{array}{l}\text { Patient lives with } \\
\text { partner } \\
\text { (reference }=\text { no) }\end{array}$ & $1.11(0.55-2.23)$ & \\
\hline $\begin{array}{l}\text { Functional status } \\
\text { at start of case } \\
\text { management } \\
\text { (reference = little or } \\
\text { not limited) }\end{array}$ & $0.66(0.35-1.23)$ & \\
\hline $\begin{array}{l}\text { Secondary diagnosis } \\
(\text { reference }=\text { no) }\end{array}$ & $1.52(0.81-2.85)$ & \\
\hline \multicolumn{3}{|l|}{ Characteristics of contacts } \\
\hline $\begin{array}{l}\text { Moment case } \\
\text { management } \\
\text { started } \\
\text { (reference = late) }\end{array}$ & $0.46(0.24-0.88)$ & \\
\hline $\begin{array}{l}\text { Case manager } \\
\text { had } 6 \text { or more } \\
\text { contacts with } \\
\text { patient } \\
\text { (reference }=\text { no) }\end{array}$ & $1.31(0.71-2.41)$ & \\
\hline \multicolumn{3}{|l|}{$\begin{array}{l}\text { First contact between } \\
\text { case manager } \\
\text { and GP was: } \\
\text { (reference = no contact) }\end{array}$} \\
\hline $\begin{array}{l}\text { In the last month } \\
\text { of the patient's life }\end{array}$ & $3.63(1.77-7.46)$ & \\
\hline $\begin{array}{l}\text { More than } 1 \text { month } \\
\text { before patient's death }\end{array}$ & $8.10(3.07-21 \cdot 36)$ & \\
\hline \multicolumn{3}{|l|}{ Tasks of the case manager } \\
\hline $\begin{array}{l}\text { The case manager } \\
\text { helped with referral } \\
\text { to or involvement } \\
\text { of other care providers }\end{array}$ & $11.52(5 \cdot 06-26 \cdot 22)$ & $\begin{array}{l}6 \cdot 33 \\
(2 \cdot 50-16 \cdot 01)\end{array}$ \\
\hline $\begin{array}{l}\text { The case manager } \\
\text { helped with referral } \\
\text { to or involvement } \\
\text { of specialized } \\
\text { palliative care }\end{array}$ & $9.60(4.09-22 \cdot 50)$ & \\
\hline
\end{tabular}


Plas, A.G.M. van der, Onwuteaka-Philipsen, B.D., Vissers, K.C., Deliens, L., Jansen, W.J.J., Francke, A.L. Appraisal of cooperation with a palliative care case manager by general practitioners and community nurses: a cross-sectional questionnaire study. Journal of Advanced Nursing: 2016, 72(1), 147-157

Table 3 (Continued).

\begin{tabular}{|c|c|c|}
\hline & \multicolumn{2}{|c|}{$\begin{array}{l}\text { GP }(n=168)^{*} \\
\text { The case manager helped to } \\
\text { realize/accomplish appropriate } \\
\text { care for this patient } \\
\text { (reference = do not agree, } \\
\text { totally disagree, don't know) }\end{array}$} \\
\hline & $\begin{array}{l}\text { Univariate } \\
\text { OR (C) }\end{array}$ & $\begin{array}{l}\text { Multivariate }^{\dagger} \\
\text { OR }(\mathrm{CI})\end{array}$ \\
\hline $\begin{array}{l}\text { The case manager } \\
\text { helped coordinate } \\
\text { the care from the } \\
\text { care providers involved }\end{array}$ & $18.72(5.43-64.61)$ & \\
\hline $\begin{array}{l}\text { The case manager took } \\
\text { care of things I did } \\
\text { not have time for }\end{array}$ & $15.40(6.54-36 \cdot 26)$ & $\begin{array}{l}5 \cdot 44 \\
(2 \cdot 03-14 \cdot 58)\end{array}$ \\
\hline $\begin{array}{l}\text { It was clear what kind } \\
\text { of support I could } \\
\text { expect from the } \\
\text { case manager }\end{array}$ & $6.25(3.09-12.63)$ & $3.18(1.32-7.65)$ \\
\hline $\begin{array}{l}\text { I knew when the case } \\
\text { manager could be } \\
\text { contacted }\end{array}$ & $5.52(2.82-10.79)$ & \\
\hline
\end{tabular}

* Missing values between 0 and 8 . Reported are odds ratios (OR) with $95 \%$ confidence intervals not including the value 1 are considered statistically significant and are boldfaced.

tThe $-2 \log$ likelihood of this model is $155 \cdot 37$. 
Plas, A.G.M. van der, Onwuteaka-Philipsen, B.D., Vissers, K.C., Deliens, L., Jansen, W.J.J., Francke, A.L. Appraisal of cooperation with a palliative care case manager by general practitioners and community nurses: a cross-sectional questionnaire study. Journal of Advanced Nursing: 2016, 72(1), 147-157

Table 4 Logistic regression analyses on characteristics associated with community nurses' ratings of whether the case manager helped to realize appropriate care for the patient.

\begin{tabular}{|c|c|c|}
\hline & \multicolumn{2}{|c|}{$\begin{array}{l}\text { Community nurse }(n=125)^{*} \\
\text { The case manager helped to } \\
\text { realize/accomplish appropriate care } \\
\text { for this patient (reference =do not } \\
\text { agree, totally disagree, don't know) }\end{array}$} \\
\hline & $\begin{array}{l}\text { Univariate } \\
\text { OR (C) }\end{array}$ & $\begin{array}{l}\text { Multivariate } \\
\text { OR (C) }\end{array}$ \\
\hline \multicolumn{3}{|l|}{ Patient characteristics } \\
\hline Age of patient & $0.98(0.95-1.01)$ & \\
\hline $\begin{array}{l}\text { Sex of patient } \\
\quad(\text { reference }=\text { male) }\end{array}$ & $0.97(0.48-1.95)$ & \\
\hline $\begin{array}{l}\text { Patient lives alone } \\
\quad(\text { reference }=\text { no) }\end{array}$ & $0.85(0.37-1.98)$ & \\
\hline $\begin{array}{l}\text { Patient lives with } \\
\text { partner }(\text { reference }=\text { no) }\end{array}$ & $1.14(0.53-2.45)$ & \\
\hline $\begin{array}{l}\text { Functional status at } \\
\text { start of case } \\
\text { management } \\
\text { (reference = little or } \\
\text { not limited) }\end{array}$ & $0.59(0.29-1.20)$ & \\
\hline $\begin{array}{l}\text { Secondary diagnosis } \\
(\text { reference }=\text { no) }\end{array}$ & $0.92(0.45-1.89)$ & \\
\hline \multicolumn{3}{|l|}{ Characteristics of contacts } \\
\hline $\begin{array}{l}\text { Moment that case } \\
\text { management started } \\
\text { (reference = late) }\end{array}$ & $1.72(0.82-3 \cdot 60)$ & \\
\hline $\begin{array}{l}\text { Case manager had six } \\
\text { or more contacts with } \\
\text { patient (reference }=\text { no) }\end{array}$ & $2.30(1.13-4.65)$ & \\
\hline \multicolumn{3}{|l|}{$\begin{array}{l}\text { First contact between } \\
\text { case manager and } \\
\text { community nurse was: } \\
\text { (reference = no } \\
\text { contact) }\end{array}$} \\
\hline $\begin{array}{l}\text { In the last month of } \\
\text { the patient's life }\end{array}$ & $2.91(1.24-6.81)$ & \\
\hline $\begin{array}{l}\text { More than } 1 \text { month } \\
\text { before patient's death }\end{array}$ & $3.99(1.49-10.70)$ & \\
\hline \multicolumn{3}{|l|}{ Tasks of the case manager } \\
\hline $\begin{array}{l}\text { The case manager } \\
\text { helped with referral } \\
\text { to or involvement of } \\
\text { other care providers }\end{array}$ & $7 \cdot 26(3.29-16 \cdot 04)$ & $\begin{array}{l}3 \cdot 21 \\
(1 \cdot 30-7 \cdot 93)\end{array}$ \\
\hline $\begin{array}{l}\text { The case manager } \\
\text { helped with referral } \\
\text { to or involvement of } \\
\text { specialized palliative } \\
\text { care }\end{array}$ & $11.39(4 \cdot 28-30 \cdot 35)$ & $\begin{array}{l}6 \cdot 63 \\
(2 \cdot 30-19 \cdot 10)\end{array}$ \\
\hline $\begin{array}{l}\text { The case manager } \\
\text { helped coordinate the } \\
\text { care from the care } \\
\text { providers involved }\end{array}$ & $8.20(3.08-21.85)$ & \\
\hline
\end{tabular}


Plas, A.G.M. van der, Onwuteaka-Philipsen, B.D., Vissers, K.C., Deliens, L., Jansen, W.J.J., Francke, A.L. Appraisal of cooperation with a palliative care case manager by general practitioners and community nurses: a cross-sectional questionnaire study. Journal of Advanced Nursing: 2016, 72(1), 147-157

Table 4 (Continued).

\begin{tabular}{|c|c|c|}
\hline & \multicolumn{2}{|c|}{$\begin{array}{l}\text { Community nurse }(n=125)^{*} \\
\text { The case manager helped to } \\
\text { realize/accomplish appropriate care } \\
\text { for this patient (reference =do not } \\
\text { agree, totally disagree, don't know) }\end{array}$} \\
\hline & $\begin{array}{l}\text { Univariate } \\
\text { OR }(\mathrm{CI})\end{array}$ & $\begin{array}{l}\text { Multivariate }{ }^{\dagger} \\
\text { OR }(\mathrm{CI})\end{array}$ \\
\hline $\begin{array}{l}\text { The case manager took } \\
\text { care of things I did not } \\
\text { have time for }\end{array}$ & $4.59(1.79-11.80)$ & \\
\hline $\begin{array}{l}\text { It was clear what kind } \\
\text { of support I could } \\
\text { expect from the case } \\
\text { manager }\end{array}$ & $3.72(1.61-8.62)$ & \\
\hline $\begin{array}{l}\text { I knew when the case } \\
\text { manager could be } \\
\text { contacted }\end{array}$ & $6.00(2 \cdot 37-15 \cdot 20)$ & $\begin{array}{l}3.65 \\
(1.23-10-81)\end{array}$ \\
\hline
\end{tabular}

* Missing values between 0 and 8 . Reported are odds ratios (OR) with $95 \%$ confidence intervals not including the value 1 are considered statistically significant and are boldfaced.

${ }^{\dagger}$ The $-2 \log$ likelihood of this model is 124.98 . 